\title{
The origin of Telemarkites from the Mesoproterozoic of Telemark, Norway
}

\author{
Emil Gyøry' , Øyvind Hammer², Knut Jorde ${ }^{3}$, Hans Arne Nakrem², Michaël Swajda² \\ \& Mathew Domeier ${ }^{4}$
}

\author{
${ }^{1}$ Einarbakken 63, 3744 Skien, Norway. \\ ${ }^{2}$ Natural History Museum, University of Oslo, P.O. Box 1172 Blindern, 0318 Oslo, Norway. \\ ${ }^{3}$ Uranienborgveien 25, 0355 Oslo, Norway. \\ ${ }^{4}$ Centre for Earth Evolution and Dynamics, University of Oslo, P.O, Box 1172 Blindern, 0318 Oslo, Norway.
}

E-mail corresponding author (Øyvind Hammer): ohammer@nhm.uio.no

\begin{abstract}
The possible macrofossil Telemarkites enigmaticus from the Mesoproterozoic Gjuve Formation, Telemark supracrustals, southern Norway, was described by Dons in 1959. We here present finds of similar, but larger structures from the somewhat older Åmot Formation (c. 1150-1250 Ma). The elongated, strongly oriented, nodular structures are up to $25 \mathrm{~cm}$ long with a carbonate-rich core, and occur in metasandstones of probable lacustrine origin. The structures and surrounding rocks have been studied with a number of techniques, including XRD, XRF, petrographic thinsections, SEM-EDS, X-ray and CT imaging, hyperspectral imaging, anisotropy of magnetic susceptibility, stable isotope analysis $\left(\delta^{13} \mathrm{C}\right.$ and $\left.\delta^{18} \mathrm{O}\right)$ and palynological preparation. Convoluted and domed beds could represent metamorphosed microbialites, deriving from algal or bacterial mats. The nodular structures remain enigmatic, but may represent oncoids, desiccation features (rollup structures), early diagenetic concretions shaped by groundwater flow, or macrofossils of unknown biological affinity. The structure Telemarkites giganticus Gyøry, Hammer, Jorde, Nakrem, Swajda \& Domeier sp. nov. is formally described.
\end{abstract}

Keywords: Telemarkites, Mesoproterozoic, Telemark supracrustals, Gjuve Formation

Received 06. October 2017 / Accepted 19. January 2018 / Published online 06. April 2018

\section{Introduction}

While stromatolites and other sedimentary structures formed by the action of microbes (microbialites) are common in Mesoproterozoic rocks, large macrofossils of eukaryotes are rare and partly controversial. Examples include the possible alga Grypania (1.9-1.3 Ga; e.g., Han \& Runnegar, 1992; Knoll, 2014), forming up to $24 \mathrm{~mm}$-wide coils, the possible eukaryote Horodyskia, forming chains of $\mathrm{mm}$-sized spherical bodies (Knoll et al., 2006), and the probable filamentous red alga Bangiomorpha (c. $1.2 \mathrm{Ga}$; Butterfield, 2000). Mesoproterozoic metazoans are even more questionable, with the end-Mesoproterozoic wormlike Parmia (c. 1.0 Ga; Gnilovskaya, 1998) being a possible example.
Dons (1959) found and described relatively large (up to $10 \mathrm{~cm}$ long) elongated nodules from the Mesoproterozoic Gjuve Formation, Telemark County, Norway. $\mathrm{He}$ extensively discussed the origin of these nodules, citing personal communication with a number of experts in Europe and USA. Arguments for both an inorganic and an organic origin were presented by the experts and no consensus was reached. In order to reflect their uncertain origin, Dons designated them Telemarkites enigmaticus. He did, however, seemingly believe them to be fossils, stating that he felt "the future explanation will be one of two: 1) the nodules are concretions formed by intervention of algae, or 2) the nodules represent sponges" (Dons, 1959). An organic origin was later supported by the find of putative algal colonies,

Gyøry, E., Hammer, Ø., Jorde, K., Nakrem, H.A., Swajda, M. \& Domeier, M. 2018: The origin of Telemarkites from the Mesoproterozoic of Telemark, Norway. Norwegian Journal of Geology 98, 25-39. https://dx.doi.org/10.17850/njg98-1-03. 
reminiscent of Cyanophyceae (Pflug \& Strübel, 1969) in the material collected by Dons. However, given the numerous, similar pseudofossils later demonstrated to be due to inorganic processes or contamination (e.g., Schopf \& Klein, 1992; Schopf et al., 2010), the microfossils illustrated by Pflug and Strübel seem to be of dubious nature. In addition, they were not shown to be exclusively associated with the nodules. Little further attention has later been given to the question of the origin of Telemarkites enigmaticus, except for scattered references to it as an inorganic pseudofossil. Schopf \& Klein (1992, p. 873) thus dismissed Telemarkites as a "nonbiogenic siliceous concretion" without giving further details.

During geological mapping in the late 1960s, the senior author observed some curious nodules in Precambrian sediments at the small Lake Breidvatn in the western part of Telemark. The structures were somewhat similar to the Telemarkites enigmaticus previously described by Dons (1959) from Haugli, some $25 \mathrm{~km}$ east-northeast of Breidvatn. The structures at Breidvatn were, however, significantly larger, reaching a length of $25 \mathrm{~cm}$, and were informally described in the senior author's unpublished thesis (Gyøry, 1972, p. 16-21) as Telemarkites giganticus. Somewhat surprisingly, none of the Telemarkites structures have been studied since then. In this paper we will give a thorough description of Telemarkites giganticus and discuss possible mechanisms for their origin.

\section{Geological setting}

All the Telemarkites structures occur in a thick succession of volcanic and sedimentary rocks designated as the Bandak Group, which is part of the supracrustal Telemark Suite that covers a large part of the county of Telemark (Dons, 1959). The geographical extent of these rocks, which are currently more informally designated as the Telemark supracrustals, can be found on the regional geological maps Skien (Dons \& Jorde, 1978) and Odda (Sigmond, 1998).

Recent mapping has shown that the Breidvatn sandstones belong to the Åmot Formation in the lowermost part of the Bandak Group (Sigmond et al., 2015). Similar fossils at another location to the southeast of Breidvatn also occur in the Åmot Formation sandstone, apparently at the same stratigraphic level. The Telemarkites enigmaticus at Haugli and similar structures at Mostøyl occur in nodular beds that constitute a part of the alternating greenstones and sandstones of the Gjuve Formation in the upper part of the Bandak Group (Dons, 1959).

The Telemark supracrustals have been extensively dated by radiometric methods, with ages ranging from c. $1050 \mathrm{Ma}$ to c. $1500 \mathrm{Ma}$ (Dahlgren et al., 1990). The corresponding age range for the Bandak Group is from c. 1050 to at least $1230 \mathrm{Ma}$. So far, the Åmot Formation has not been dated, but the Fjellhovdane rhyolite in the overlying Skinnut Formation has recently been dated to $1233 \pm 10 \mathrm{Ma}$ (Roberts et al., 2011), thus providing a minimum age for the Telemarkites giganticus. The Telemarkites enigmaticus of Dons (1959) belongs to the upper part of the Bandak Group and is therefore clearly somewhat younger than this, but must also be of Mesoproterozoic age.

\section{Material and methods}

The Telemarkites giganticus nodules were first found at the southeastern edge of the Breidvatn lake, located in the Tokke municipality, $9 \mathrm{~km}$ southwest of the small town of Dalen, which is some $160 \mathrm{~km}$ west-southwest of Oslo. The lake lies in an area with sparse mountain forest, some $2.5 \mathrm{~km}$ from the nearest road. The structures occur in a light grey, slightly schistose metasandstone, cropping out at the southeastern side of the lake (Fig. 1 , locations $1-2$ ). The sandstone is partly covered by moss, but the structures can be observed on uncovered, glacially striated surfaces (Fig. 2) and on vertical joint surfaces in an area adjacent to the lake. They can most easily be found at the water's edge on the tip of the westernmost of the three points along the southeastern side of the lake, where solution of carbonate minerals has resulted in a series of circular grooves with a central depression on the rock face. An additional locality with large exposed bedding planes (several hundred sq. m.) containing Telemarkites giganticus was found southeast of the Breidvatn lake, close to the Fylkesvei 45 road (Fig. 1, location 3). At this locality we measured sizes and orientations of nodules in the field.

The sandstone is rather competent, presenting a challenge for sampling. The solution was found by selecting a large, $100 \times 60 \times 35 \mathrm{~cm}$ block at Breidvatn that contained a continuous sequence of sediments with nodules. The exact original location of the block could not be established, but it was clearly of strictly local origin. For easier handling, the half-ton block was split into three slabs along bedding planes during midwinter. The slabs were transported by snowmobile and sledge to the road, and then, during spring, to Skien by lorry. The slabs were cut by saw into smaller pieces, selected parts of which were cut into $0.5-1 \mathrm{~cm}$-thick slices for further study.

The sampled nodules were investigated by semiquantitative chemical analysis with X-ray fluorescence and X-ray diffraction by the Norsk Hydro Research Centre in Porsgrunn. The nodules can be divided into a dark, outer membrane, a pinkish-grey intermediate part and a pale green inner core. Each of these parts were analysed, and also the rock matrix, i.e., the sandstone containing the nodules. 


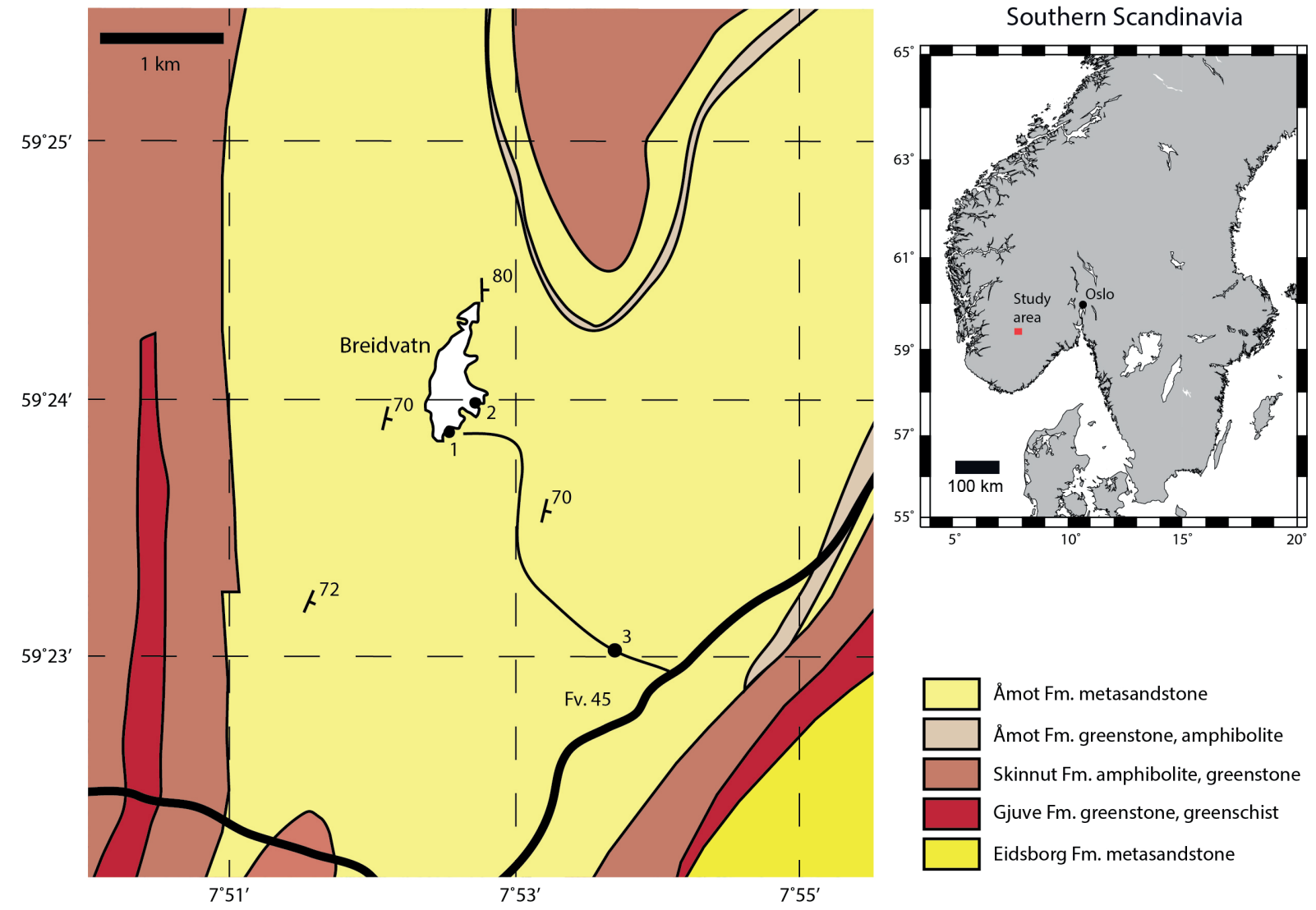

Figure 1. Simplified geological map of the Breidvatn area, Telemark, southern Norway, with the Telemarkites giganticus locations indicated (1-3). Based on Sigmond et al. (2015); see also Gyøry (1972).

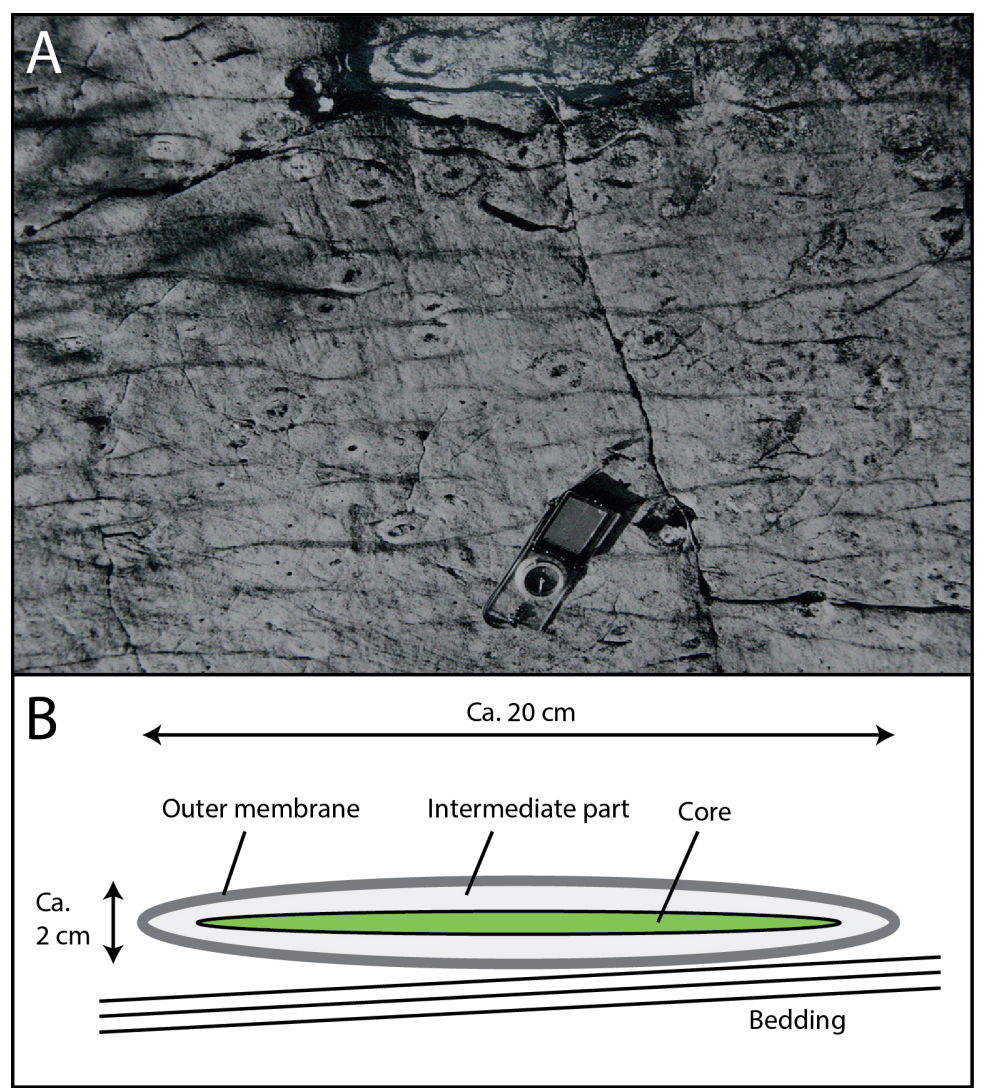

Figure 2. (A) Evenly distributed Telemarkites giganticus (cross sections) on glacially striated surface, Lake Breidvatn (Fig. 1, loc. 1). Photographed in 1972. (B) Sketch of the morphology of the nodules. 
Thin-sections were prepared at the Institute for Geosciences, University of Oslo, and studied with transmitted-light microscopy with and without planepolarised light (crossed nicols) at the Natural History Museum, University of Oslo (NHM). Whole thinsection slides were scanned with a Nikon LS4000 slide scanner. The total areas of calcite and magnetite grains were measured in four concentric zones of two nodules, by colouring the minerals in Photoshop and using the histogram function.

$\mathrm{X}$-ray and CT imaging used a Nikon Metrology XT H 225 ST microfocus X-ray tomography instrument at NHM. Simple X-ray imaging (i.e., not CT) of rock slices was carried out at $80 \mathrm{kV}, 200 \mathrm{uA}, 1 \mathrm{~s}$ exposure time, with averaging of 32 images for noise reduction. CT of larger blocks used $200 \mathrm{kV}, 200 \mathrm{uA}, 1 \mathrm{~s}$ exposure time, 3017 rotational projections, and a $0.25 \mathrm{~mm}$ tin filter. Because of limited X-ray contrast, 3D reconstruction required manual segmentation of individual CT slices and was followed by surface rendering in the Avizo software, ver. 8.01 (FEI Inc.).

Thin-sections were imaged with the Hitachi S-3600N SEM-EDS at NHM. Point measurements were used to aid the petrographic interpretation, and element maps were produced across one Telemarkites nodule.

Nine powdered samples were drilled out along a transect across a Telemarkites giganticus nodule, PMO 228.553, and carbonate was analysed for stable isotopes $\left(\delta^{13} \mathrm{C}\right.$ and $\delta^{18} \mathrm{O}$ ) at the Institute for Geosciences, University of Bergen. Powdered samples were analysed on Finnigan MAT 251 and MAT 253 mass spectrometers coupled to automated Kiel devices. The data are reported on the VPDB scale calibrated with NBS-19.

Hyperspectral imaging was carried out with a Hyspex shortwave infrared (SWIR) hyperspectral camera at NEO Inc. in Oslo. The camera has 288 spectral bands from 950 to $2500 \mathrm{~nm}$ wavelength. The samples were scanned with a $30 \mathrm{~cm}$ lens $(0.26 \mathrm{~mm}$ pixel resolution). Images were produced from the hyperspectral data with two different methods: simple visualisation of selected bands in the $R, G$ and $B$ channels in the GLIMPS software (ReSe Applications) and Principal Components Analysis (PCA) with Matlab (Mathworks, Inc.).

Anisotropy of magnetic susceptibility (AMS) was measured in seven samples drilled from a sandstone block with Telemarkites giganticus, using an Agico MFK1 Kappabridge at the Ivar Giæver Geomagnetic Laboratory, University of Oslo. The seven samples were taken only from the rock matrix. The coordinate system was aligned along one nodule ( $\mathrm{x}$ axis), normal to the nodule and parallel with the bedding planes (y axis) and normal to bedding ( $\mathrm{z}$ axis). Samples were drilled parallel to both the $\mathrm{x}$ and the $\mathrm{y}$ axes.
The material is deposited at the Natural History Museum, University of Oslo, with PMO numbers ("Paleontological Museum Oslo collection").

\section{Results}

\section{Morphology and field appearance}

Most of the Telemarkites giganticus nodules occur fairly evenly distributed within the sandstone (Fig. 2). The long axis of most of the nodules is parallel with the bedding plane but some are slightly oblique to bedding. The long axis also shows a strong orientation along the bedding planes (Fig. 3), and we have seen only rare specimens oriented at large angles to the trend. The diameters of cross sections show a near-normal distribution with a mean of $18 \mathrm{~mm}$, but varying from 7 to $33 \mathrm{~mm}$ (Fig. 4). The smallest diameters were probably measured close to the tips of the nodules, therefore not reflecting the maximal thickness. The cross sections appear somewhat flattened, which is partly due to slightly oblique orientation with respect to the rock face, but the 3D CT imaging (see below) confirms some degree of vertical compression.

\section{Serial sectioning}

The shape and internal structure of the nodules can most easily be observed on wet cut surfaces of thin slices, which show that the typical nodule is cigar-shaped, tapering off at both ends, with a length of some 20-25

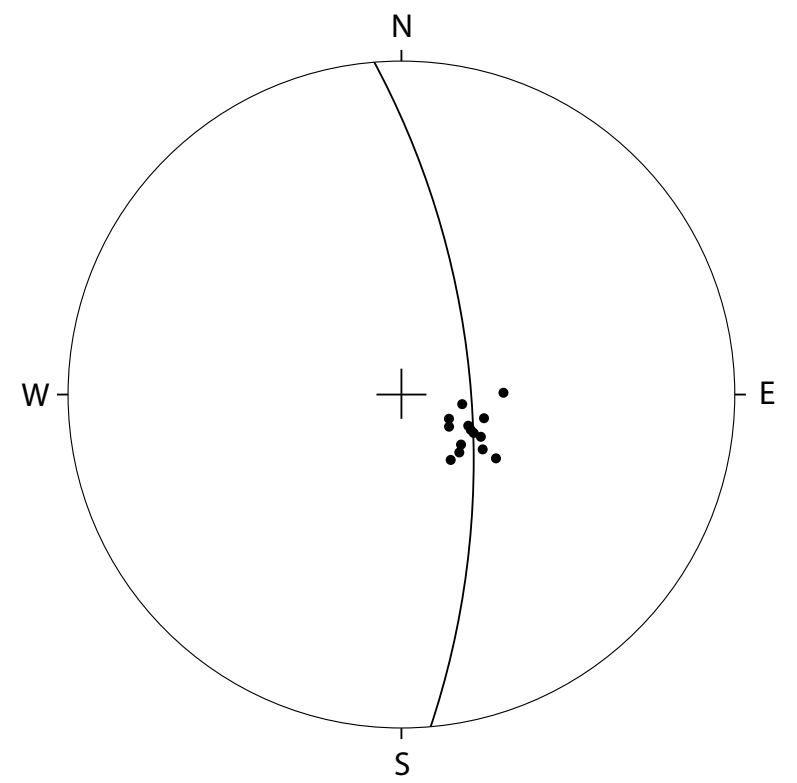

Figure 3. Stereoplot (Schmidt projection to lower hemisphere) of long axis of Telemarkites giganticus southeast of Breidvatn (Fig. 1, loc. 3, $N=14$ ). Orientation of the bedding plane is shown as a great circle (strike $355^{\circ}$, dip $73^{\circ} \mathrm{E}$ ). 


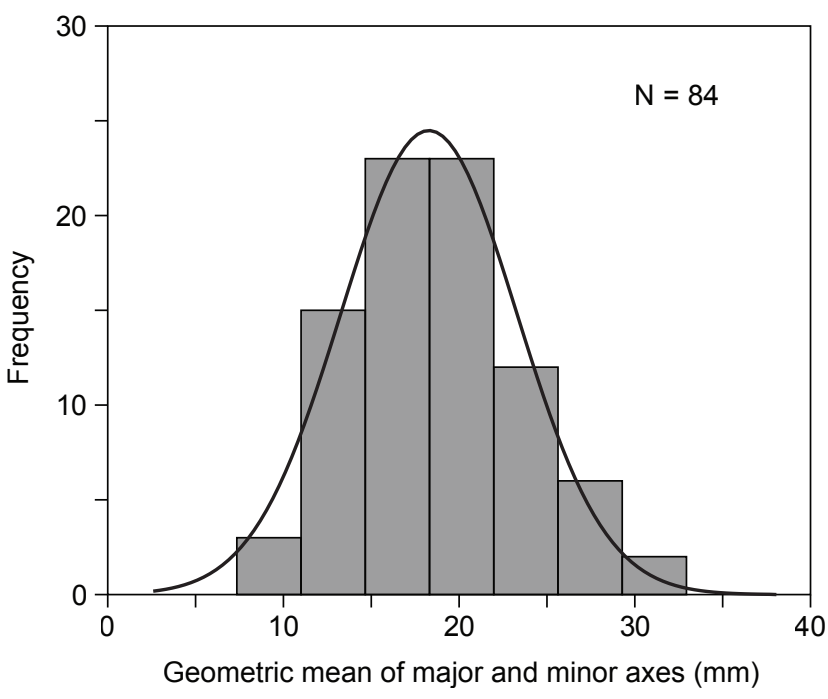

Figure 4. Histogram of geometric means of intermediate and minor axes of Telemarkites giganticus observed in cross section southeast of Lake Breidvatn (Fig. 1, loc. 3). The geometric mean corresponds to the diameter of a circle with the same area as the observed ellipse. The mean is $18 \mathrm{~mm}$, standard deviation $5 \mathrm{~mm}$. The distribution is indistinguishable from a normal distribution (Shapiro-Wilk $\mathrm{W}=$ $0.98, \mathrm{p}=0.20$ ); the least-squares fitted normal is indicated (black line).

cm (Fig. 5). Cross sections are usually ellipsoidal, with a horizontal diameter of $5-7 \mathrm{~cm}$ and a vertical diameter of 3-4 cm (Fig. 6). These observations were made on sections cut roughly parallel with and normal to the long axis. The longitudinal axis is oriented with an angle of up to $16^{\circ}$ to the bedding plane. The nodules contain a centrally located, inner core with a greenish tint and thickness of $0.4-0.7 \mathrm{~cm}$; an intermediate, pinkish-grey part; and an outer, dark membrane with a thickness of up to $5 \mathrm{~mm}$ (Fig. 2). Some stratigraphic intervals show more complex textures with domed, convolute and truncated bedding (Fig. 7).

By stacking the serial sections, it is possible to obtain a $3 \mathrm{D}$ representation of the nodules (Fig. 8), confirming the morphology described above. Similar figures were presented by Dons (1959) for Telemarkites enigmaticus.

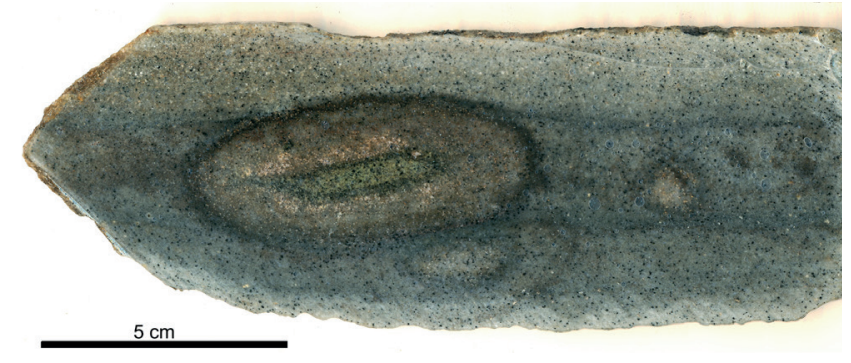

Figure 6. Cross section of hand specimen showing quartzite matrix with schistose (mica-rich) dark beds, and nodule with outer membrane (dark), intermediate part (bright) and central core (greenish). PMO 228.552.

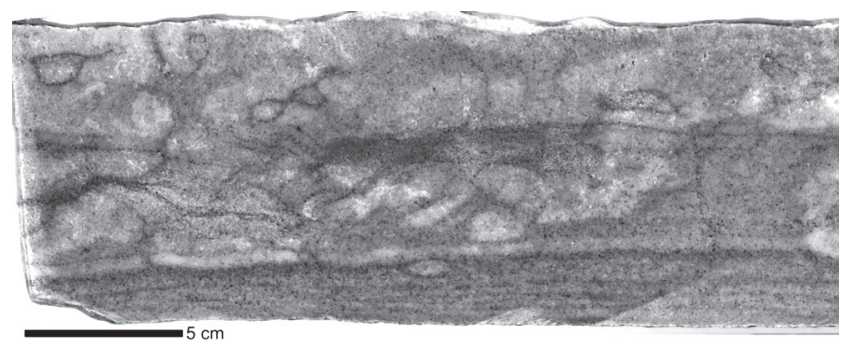

Figure 7. Complex texture with possible microbial mats and convolute bedding. Specimen taken from the nodule-bearing block collected at Breidvatn. PMO 226.936.

\section{Bulk XRD and XRF}

The results of bulk XRD and XRF analysis are compiled in Table 1, which also contains data from the Haugli Telemarkites enigmaticus that were analysed for their alkali content (Dons, 1959).

The analysis shows that the $\mathrm{SiO}_{2}$ content is significantly lower in the core of the nodules than in the intermediate part and surrounding rock matrix. The iron and calcium contents also vary, with a higher concentration in the central part than in the rock matrix. Further, there are clear differences in the alkali contents, as observed also by Dons (1959). This is particularly the case for potassium, which is significantly lower within the nodules than in the matrix. The material loss due to combustion is also higher, particularly in the core.

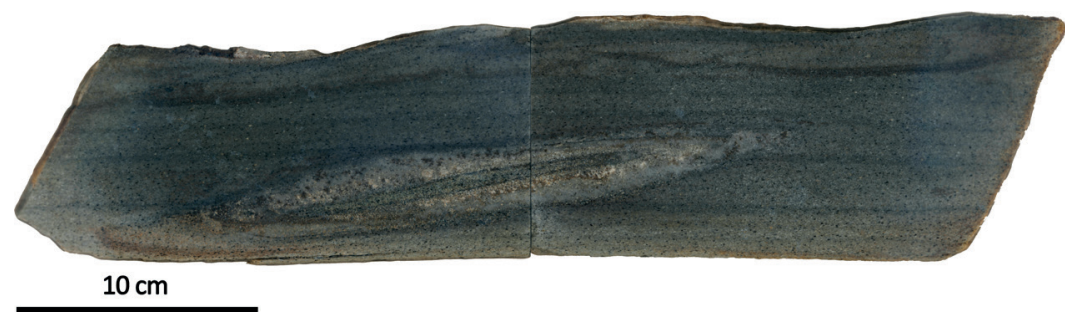

Figure 5. Longitudinal section of Telemarkites giganticus, a possible example of core extending to the end of the nodule (left). PMO 228.551/3. 

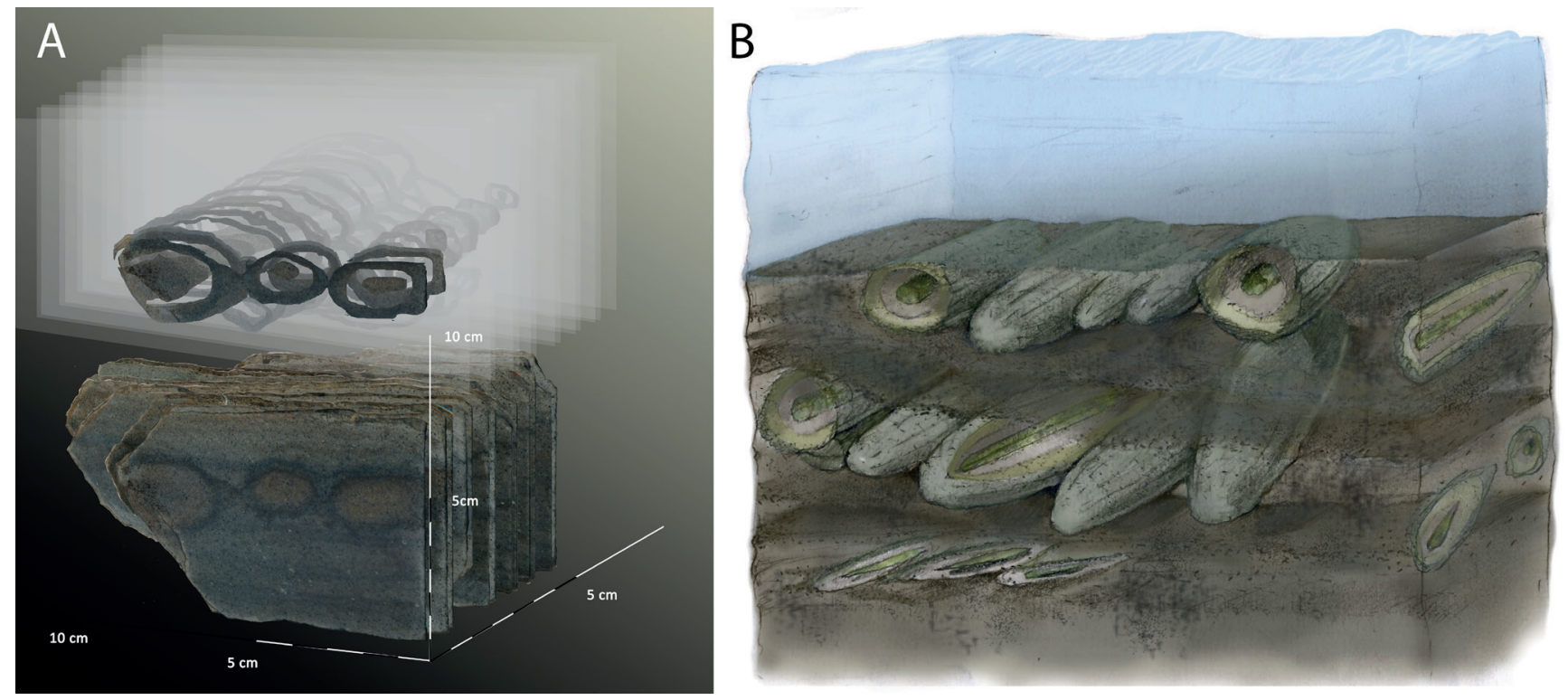

Figure 8. (A) 3D reconstructions from serial sections. (B) Artistic impression, showing morphology, preferred orientation and occasional tilting with respect to bedding.

Table 1. XRF analysis of a specimen of T. giganticus, compared with analysis of T. enigmaticus reported by Dons (1959). Values in weight percent.

\begin{tabular}{|c|c|c|c|c|c|}
\hline & \multicolumn{3}{|c|}{ Telemarkites giganticus } & \multicolumn{2}{|c|}{ T. enigmaticus } \\
\hline & Intermediate part & Core & Rock matrix & Fossils & Rock matrix \\
\hline $\mathrm{SiO}_{2}$ & 80.1 & 59.7 & 79.2 & & \\
\hline $\mathrm{TiO}_{2}$ & 0.2 & 0.2 & 0.3 & & \\
\hline $\mathrm{Al}_{2} \mathrm{O}_{3}$ & 5.6 & 7.8 & 10.7 & & \\
\hline $\mathrm{Fe}_{2} \mathrm{O}_{3}$ & 1.2 & 4.8 & 2.1 & & \\
\hline $\mathrm{MgO}$ & 0.5 & 0.8 & 0.8 & & \\
\hline $\mathrm{CaO}$ & 5.4 & 15.0 & 0.1 & & \\
\hline $\mathrm{MnO}$ & 0.2 & 0.4 & 0.01 & & \\
\hline $\mathrm{Na}_{2} \mathrm{O}$ & 2.6 & 2.3 & 0.5 & 3.88 & 4.35 \\
\hline $\mathrm{K} 2 \mathrm{O}$ & 0.7 & 1.0 & 4.4 & 0.42 & 2.04 \\
\hline $\mathrm{P}_{2} \mathrm{O}_{5}$ & 0.1 & 0.1 & 0.08 & & \\
\hline Combustion loss & 3.4 & 7.8 & 1.4 & & \\
\hline
\end{tabular}

The diffraction analysis shows significant differences between the different parts. The main components of the thin, outer membrane appear to be quartz, albite and hedenbergite, biotite, iron carbonate and chlorite minerals. It should be noted that due to the very small thickness of the membrane, parts of the matrix or the intermediate part may have been included in the analysis. The thick pinkish-grey intermediate part contains the same minerals, with calcite as a supplement. In the green central part, the calcite content is higher, and epidote and magnetite also occur. The magnetite content in the central part is so high that it attracts an adjacent magnet. The rock matrix contains, in addition to quartz, significant amounts of microcline and muscovite.

\section{Thin-section petrography}

In thin-section, the different rock phases visible on macroscale can be distinguished by their mineral composition, largely in accordance with the XRD data (Fig. 9). The rock matrix consists mainly of quartz grains, partly with irregular (sutured) boundaries indicating pressure solution, but also with significant amounts of sericite (mica) and albite together with large biotite grains. The mica content gives a grey colour. The dark beds in the matrix are even richer in mica, together with chlorite, giving them a schistose character. Calcite and magnetite are rare $(0.52 \%$ and $0.44 \%$ grain areas, respectively). 

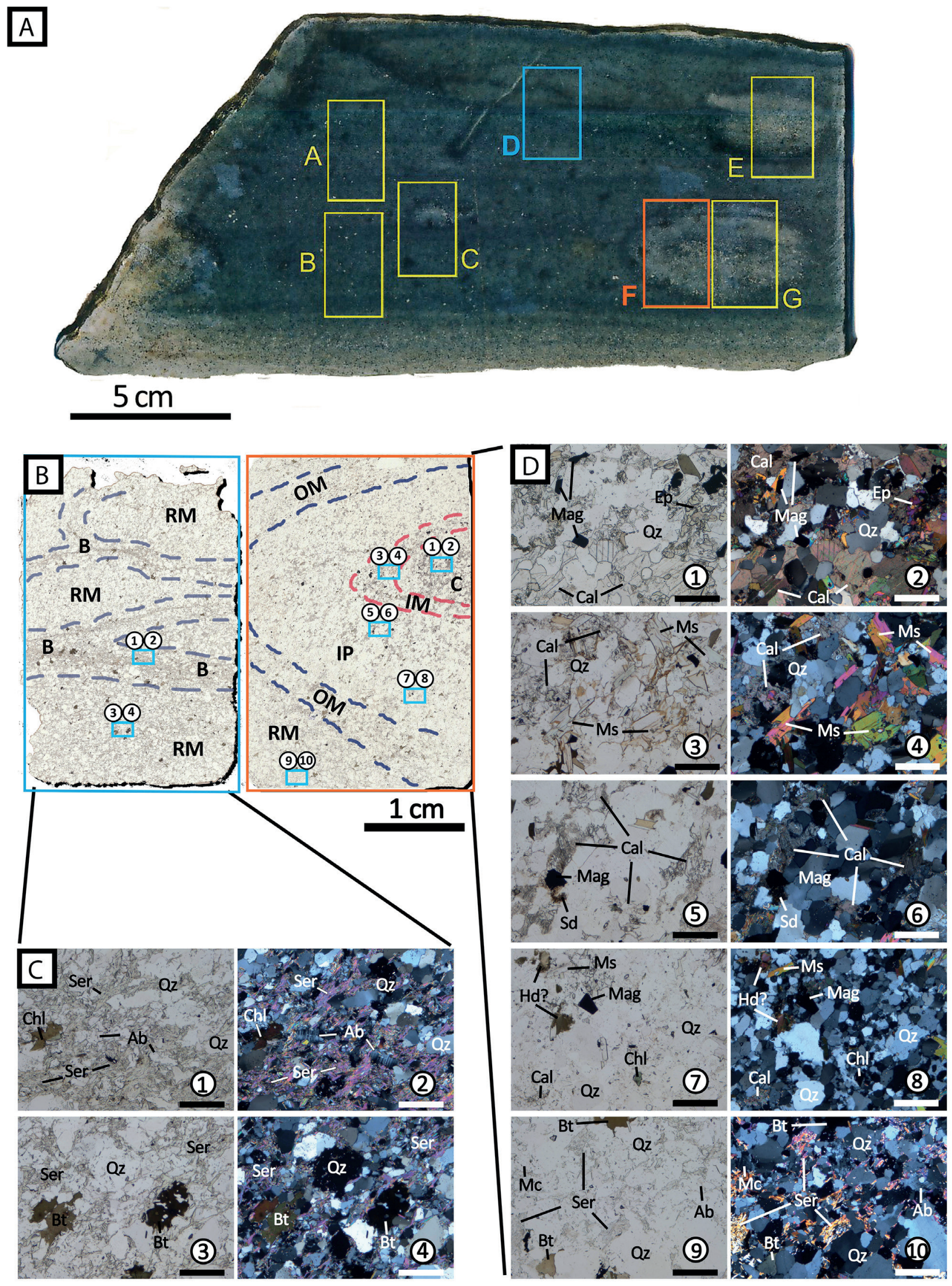

Figure 9. Petrographic thin-sections from PMO 228.553. (A) Positions of thin-sections. (B) Scans of thin-sections D and F. RM: Rock matrix; B: Bed; OM: Outer membrane; IP: Intermediate part; IM: Inner membrane; C: Core. (C) \& (D) Thin-section micrographs of nodule in planepolarised light (PPL; left column) and crossed-polarised light (XPL; right column). Ab: Albite; Bt: Biotite; Cal: Calcite; Chl: Chlorite; Ep: Epidote; Hd: Hedenbergite; Mag: Magnetite; Mc: Microcline; Ms: Muscovite; Qz: Quartz; Ser: Sericite; Sd: Siderite. Each number is associated with viewing location in B). Scale bar: $0.4 \mathrm{~mm}$. 
The outer membrane has similar composition to the matrix, but with muscovite being somewhat more common. There is no indication of grain orientation along the membrane. Calcite $(4.2 \%$ grain area) and magnetite $(0.88 \%)$ are also somewhat more common than in the matrix.

The intermediate part appears much brighter coloured than the matrix because sericite is largely absent, making quartz an even more dominant mineral, although minor amounts of muscovite and chlorite are present. Siderite and euhedral magnetite are also present but not abundant $(0.55 \%$ magnetite grain area). Calcite is common (5.8\%). The quartz grain size is noticeably larger than in the matrix.

Again in accordance with the XRD results, the core is rich in calcite $(27.1 \%$ grain area), with some epidote. Magnetite grains are common (1.45\%).

\section{Palynology}

The palynological preparations did not yield obvious palynomorphs, apart from probable modern contaminants which were recognisable by excellent preservation with a light brown colour. However, the residue did contain fragments of amorphous, black, inert organic matter, possibly originally of algal origin.

\section{SEM-EDS}

The element maps (Fig. 10) illustrate the concentration of calcite and subsidiary epidote in the core of the nodule (high Ca content), the relatively pure quartzite in the intermediate part ( $\mathrm{Si})$, and the higher phyllosilicate and feldspar abundance ( $\mathrm{Al}, \mathrm{Na}, \mathrm{K})$ in the outer membrane and matrix.

\section{X-ray and $\mathrm{CT}$ imaging}

The X-ray images of cut rock slices of Telemarkites (Fig. 11) provide visual details complementary to the other imaging techniques. Magnetite crystals are particularly visible as black dots due to the high atomic weight of iron. They occur concentrated along some beds, and particularly in the central core of the Telemarkites nodules. The X-ray images show clearly that bedding sometimes passes through the nodules, commonly seemingly deformed by them (draping), but we have not observed any bed passing through the central core. In a $3 \mathrm{D}$ reconstruction from CT data (Fig. 12), the nodule bends and passes through a planar bed, demonstrating that the kink is not tectonic. The CT reconstruction (Fig. 12) also demonstrates the elliptic cross section of the nodule, with shorter axis normal to bedding, and (in this particular case) termination of the core inside the nodule. The $3 \mathrm{D}$ morphology is otherwise difficult
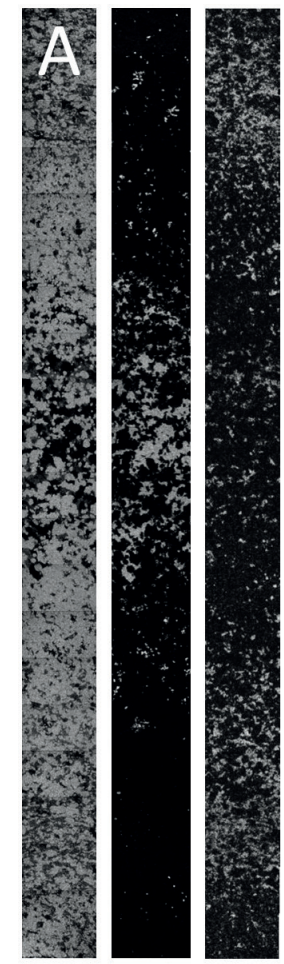

$\mathrm{Ca}$

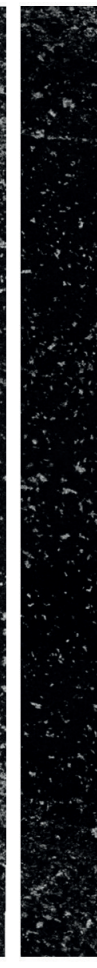

K
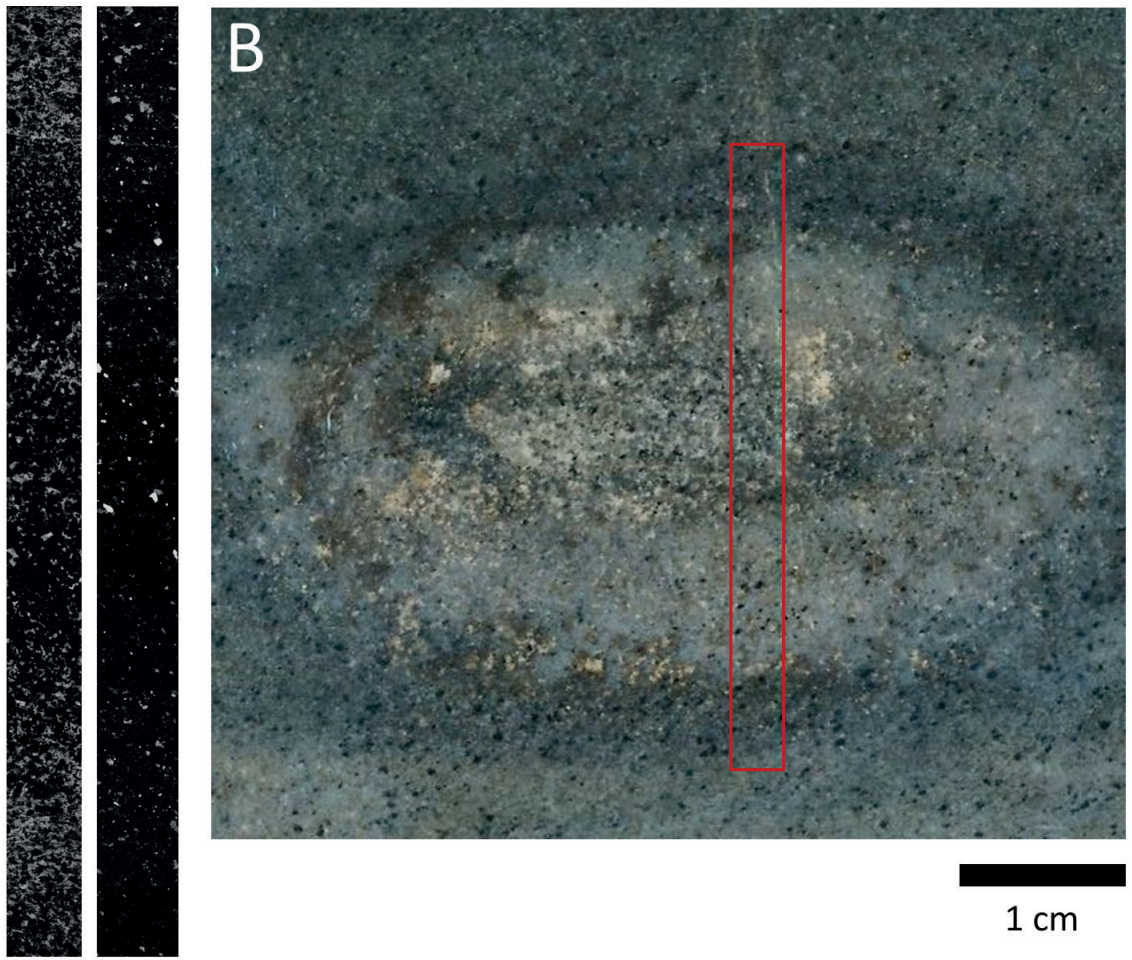

$1 \mathrm{~cm}$

Figure 10. (A) SEM-EDS maps of selected elements. Brighter tones show higher concentration (relative values only). (B) Optical photograph of polished section, showing area of SEM-EDS study. 

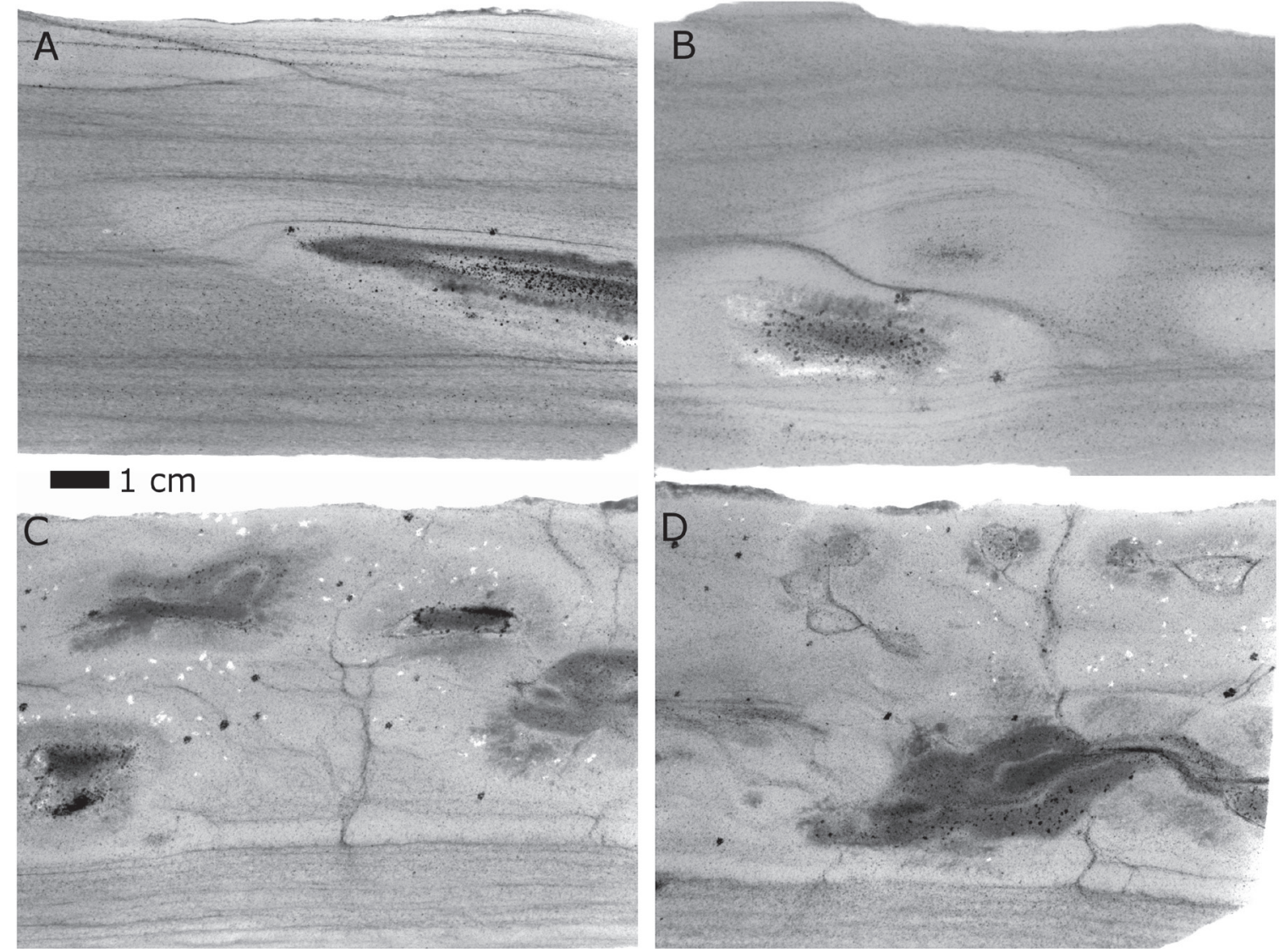

Figure 11. X-ray images of rock slices with Telemarkites giganticus. (A) Inclined nodule, PMO 228.551. (B) Touching nodules with concentration of magnetite grains in nodule cores, PMO 228.552. Note bedding passing through the nodules. (C \& D) Complex texture, possibly several compressed nodules, in upper part, and parallel lamination in lower part.

to demonstrate in outcrop and hand specimen possibly because of oblique cutting.

\section{Hyperspectral imaging}

The hyperspectral imaging (Fig. 13) confirms and adds detail to the petrographic and X-ray results. The intermediate zone and core of the nodule have IR spectra which are clearly distinct from the matrix. Furthermore, the rendering of PCA components 1-3 shows that the outer membrane (purple colour) is mineralogically distinct from the schistose beds in the matrix, shown as brown hues. Inspecting the individual components, the outer membrane is highly visible on PC3 while the beds are not. Several principal components (PC 2, 3 and 6) of the imaged specimen resolve the upper part of the outer membrane into two parallel layers.

\section{Stable isotopes}

The results of the stable isotope analysis are shown in Fig. 14. There is a clear and strong gradient in $\delta^{13} \mathrm{C}$ across the nodule, with values decreasing from $-1 \%$ in the outer membrane to $-3.87 \%$ in the core (Spearman's rs

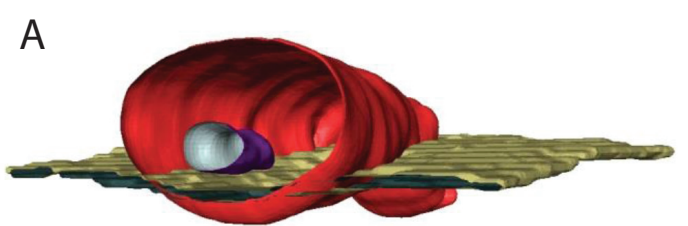

B

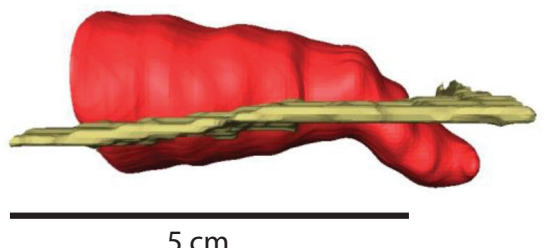

Figure 12. 3D reconstruction of partial nodule (red), nodule core (purple/gray) and one bed (gold). (A) Transversal view, (B) Lateral view. Note the bending of the nodule while the bed remains planar, and the bed passing through the nodule.

$=-0.93, \mathrm{p}<0.001)$. The oxygen isotope values are more stable, varying from $-17.95 \%$ to $-18.45 \%$, but with some tendency towards a heavier isotopic composition in the intermediate zone than at the rim and in the core. There is no correlation between $\delta^{13} \mathrm{C}$ and $\delta^{18} \mathrm{O}\left(\mathrm{r}^{2}=0.04, \mathrm{p}=\right.$ $0.62)$. 

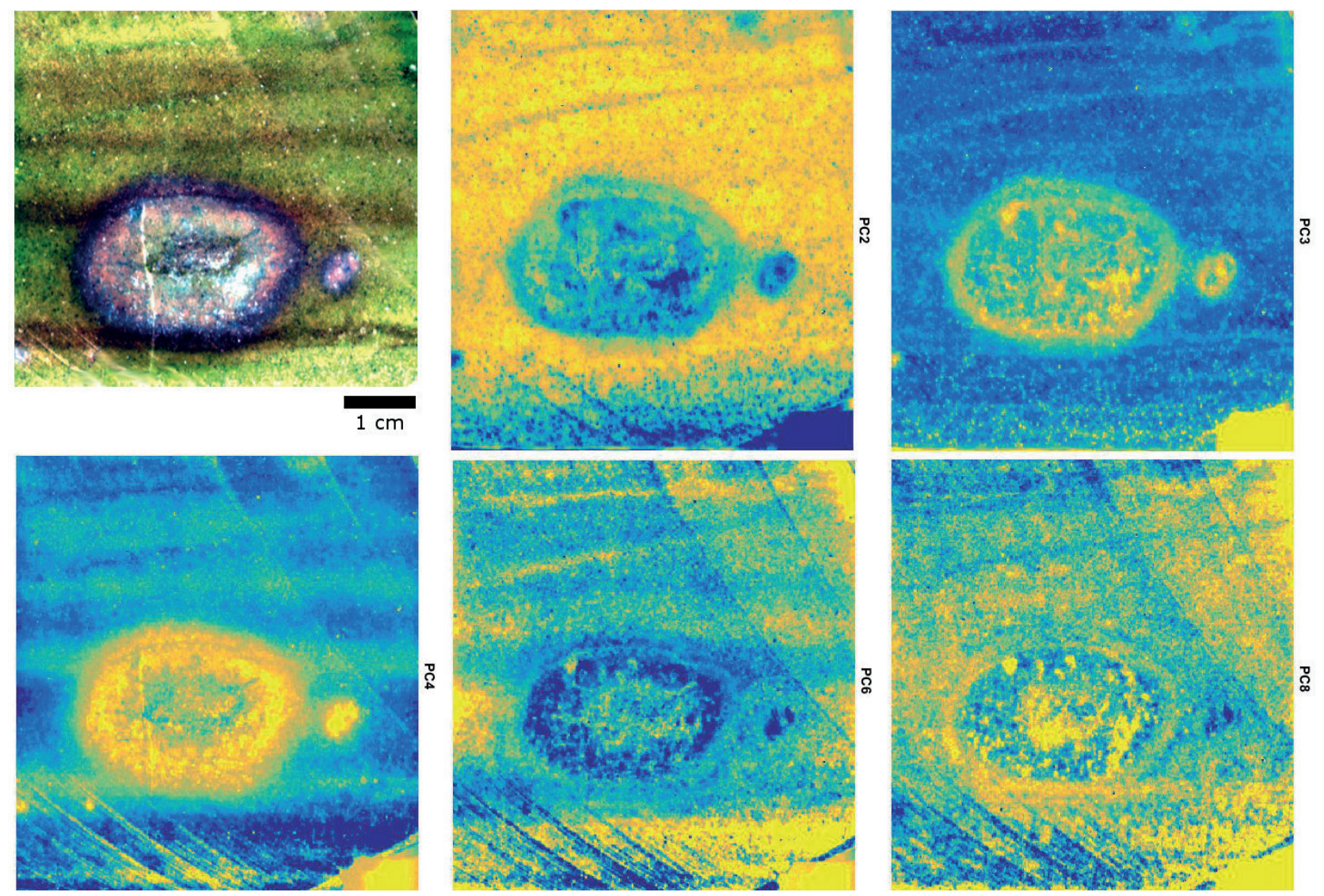

Figure 13. Hyperspectral images of specimen PMO 228.553. Top left: $1000 \mathrm{~nm}, 1500 \mathrm{~nm}$ and $2000 \mathrm{~nm}$ wavelengths, shown as RGB. Remaining panels: Principal components 2, 3, 4, 6 \& 8 rendered with a blue to yellow colour map.

\section{Anisotropy of magnetic susceptibility, and grain orientation}

The results of the AMS measurements on samples of the rock matrix are shown in Fig. 15. The bulk (sample-level) magnetic fabric is triaxial to very mildly oblate, with principal axes (maximum, intermediate and minimum axes of the susceptibility ellipsoid) of $\mathrm{K}_{1}=1.078, \mathrm{~K}_{2}=$ 1.048 and $\mathrm{K}_{3}=0.874$, respectively. $\mathrm{K}_{1}$ lies in the same plane as bedding and is parallel to the long axis of the Telemarkites nodules. $\mathrm{K}_{2}$ and $\mathrm{K}_{3}$ are normal to the long axes of the nodules and inclined $\sim 40^{\circ}$ to the bedding and pole to bedding, respectively.

A typical 'sedimentary' magnetic fabric is oblate with $\mathrm{K}_{3}$ well clustered about an axis subparallel to the pole to the bedding plane. $\mathrm{K}_{1}$ and $\mathrm{K}_{2}$ in such sedimentary fabrics are restricted to the bedding plane and these axes can either be scattered and intermixed (forming a strongly oblate fabric) or distinct and well separated (forming a more triaxial fabric). The latter case may arise by deposition under local flow, and $\mathrm{K}_{1}$ is commonly found to lie parallel or perpendicular to the flow direction, depending on the magnetic grain size and the mechanics of grain transport. In this sense, given that $\mathrm{K}_{1}$ is parallel to the long axis of the Telemarkites nodules, it would be tempting to interpret their coincidence as a primary (sedimentary) fabric reflecting organisation by local flow. However, the interpretation of the observed magnetic fabric as a sedimentary fabric is inconsistent given the high angle of the $\mathrm{K}_{3}$ axis with respect to the pole to bedding. The probable lacustrine origin of the metasandstones is likewise inconsistent with their depositional flow which was strong enough to orient the Telemarkites nodules.

Alternatively, the observed magnetic fabric could be tectonic. A standard (if simplistic) model of tectonic fabrics predicts that they will evolve from: 1) an oblate sedimentary fabric with $\mathrm{K}_{3}$ normal to bedding to 2) an intermediate stage characterised by a prolate fabric to 3 ) a triaxial fabric with $\mathrm{K}_{1}$ normal to the shortening direction. In this case, the coincidence of $\mathrm{K}_{1}$ with the long axis of the Telemarkites nodules could suggest that their shared axis was one of tension, and that the elongate shape of Telemarkites is (at least partly) tectonic. Unfortunately, it is not generally possible to estimate the magnitude of strain from the magnetic susceptibility ellipsoid.

Biotite grains are easily recognisable on the cut surfaces because of their dark colour. These grains are clearly oriented in the same direction as the nodules. We measured the major and minor axes of 30 biotite grains in the rock matrix on each of surfaces cut parallel and normal to the long axis of a nodule. The mean ratio of 

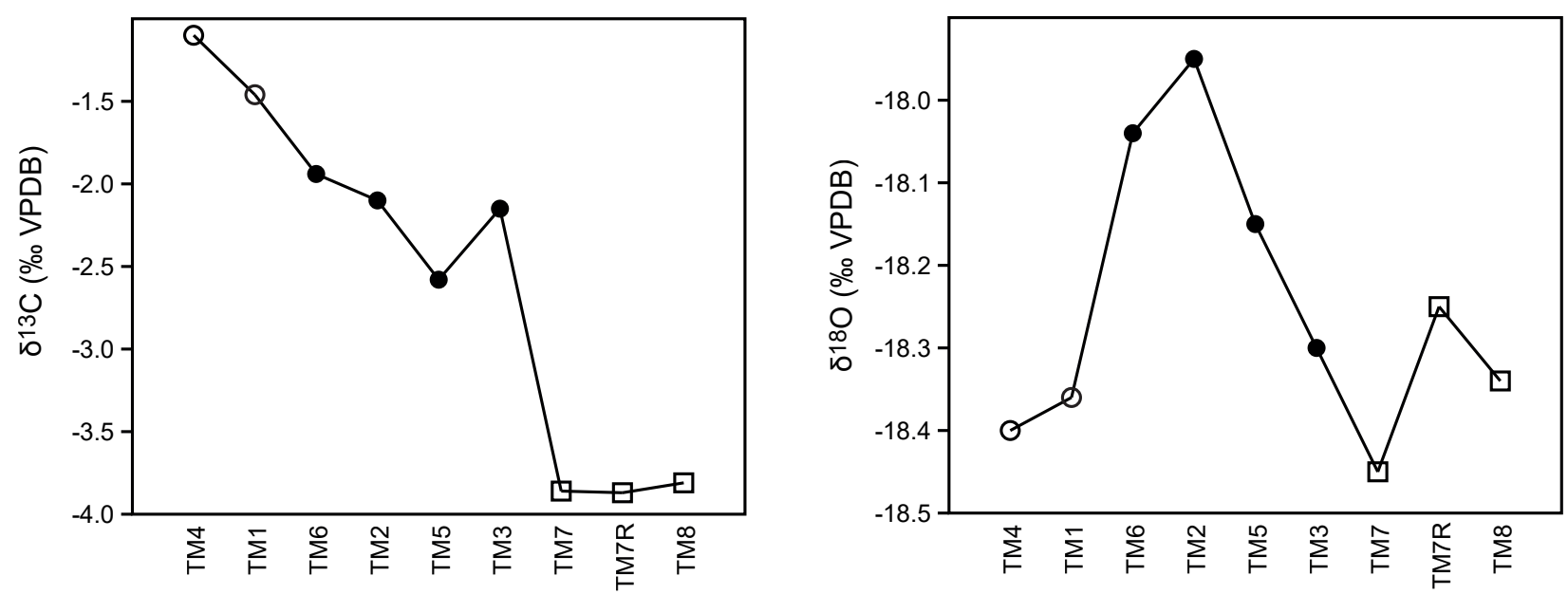

Figure 14. Carbonate isotope values of Telemarkites giganticus, PMO 228.553. Samples are ordered from rim (left; open circles) via the intermediate part (solid circles) to core (right; squares).
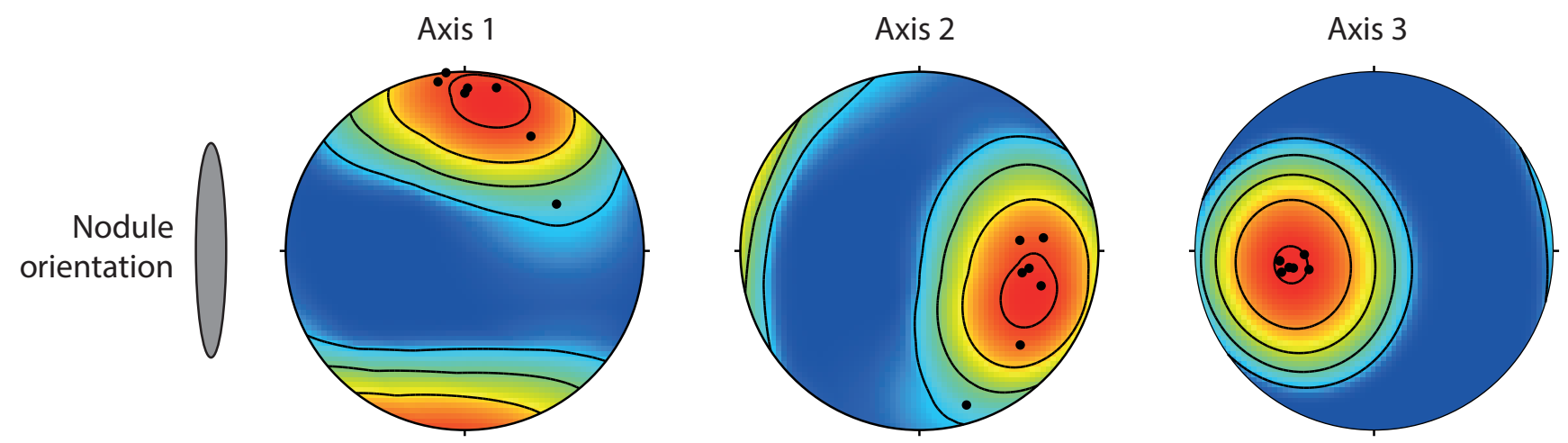

Figure 15. Stereoplots of the first, second and third principal directions of anisotropy of magnetic susceptibililty in the rock matrix, showing a well-defined triaxial magnetic fabric. Schmidt projection to the lower hemisphere.

major to minor axis on the surface along the nodule was 4.27 , i.e., very elongated cross sections of grains, while the ratio on the surface normal to the nodule was 1.34, i.e., near circular cross sections $(p<0.001$, Mann-Whitney test).

\section{Discussion}

\section{Sedimentary structures}

The dark, mica-rich bands are interpreted as altered clay beds. These beds are generally parallel and almost varvelike but beds within the interval containing the nodules can also be cross-bedded, convolute, forming domes, and truncated in a manner somewhat reminiscent of microbialites ('algal mats'). The presence of magnetite may be of interest in this context as it is in some cases considered a prokaryotic biomarker (Jimenez-Lopez et al., 2010), but then usually in the form of submicrometer crystals, in contrast with the considerably larger magnetite grains (50 to 1000 microns) seen in the Telemarkites material. Also, the magnetite grains are not organised into chains but occur scattered or in amorphous aggregates.

\section{Lineation}

The strong elongation and orientation of biotite grains demonstrate a lineation in the rock containing Telemarkites giganticus, with the same orientation as the longest axis of the nodules. The AMS analysis shows a similar orientation of the magnetic fabric, with the first principal direction $\left(\mathrm{K}_{1}\right)$ parallel to the nodules. These orientations may be due to several different processes: 1) Primary, sedimentary, current- or waveinduced orientation of grains; 2) Crystal growth during 
directional groundwater flow, as described below; or 3) A late lineation caused by tectonic deformation, probably in combination with metamorphism. The orientations of axes in the AMS data are consistent with the elongation of the nodules being due to a tectonic process, but it cannot be assessed whether the magnitude of deformation was sufficient to explain the large aspect ratio of the nodules.

\section{Model 1: Authigenic seep carbonate or hydrothermal vent chimneys}

The tube-like morphology and carbonate cement of Telemarkites are reminiscent of the authigenic carbonate gas conduits found in methane seep settings (e.g., Zwicker et al., 2015). Alternatively, the structures could represent silica chimneys of hydrothermal vents. The horizontal orientation and preferred orientation could possibly be explained by toppling and current orientation. However, the closed ends of the central cores and the lack of the distinct carbon isotope signature expected from a methane seep carbonate are strong arguments against this hypothesis.

\section{Model 2: Ripple fills, flaser bedding}

The possibility that elongated nodules could form by preferable cementation of wave ripples was briefly mentioned by McBride et al. (1994) but dismissed in favour of the groundwater flow theory described below. Singh (1969, Figs. 25 \& 26) illustrated sedimentary structures in Telemark supracrustal quartzites that are somewhat reminiscent of the Telemarkites-containing rocks described here, and he interpreted them as lenticular and flaser bedding formed by oscillation ripples. However, the oblique orientation and occasional transection of the Telemarkites nodules by the bedding speak against this interpretation for the Telemarkites. We observed oscillation ripples in the Åmot Formation in a road cut a few hundred metres from the Telemarkites locality southeast of Breidvatn (loc. 3), but no obvious ripples were found in direct association with the nodules.

\section{Model 3: Oncoids}

If the bedding textures in the host rock are interpreted as of microbialitic in origin, and given the carbonatecemented core of the Telemarkites nodules (which may have been more extensive prior to metamorphism), it is natural to interpret the nodules as oncoids, i.e., rounded concretions formed under the influence of microbial/ algal growth in a manner similar to stromatolites. Large oncoids, often tens of centimetres in size, are common in Proterozoic rocks, including lacustrine and fluvial deposits (e.g., Flügel, 2004). This idea was suggested by Dons (1959) as one of his two preferred hypotheses ("concretions formed by intervention of algae"). The strong elongation of the Telemarkites nodules, however, is not typical for oncoids, but might possibly be explained by wave action or by tectonic deformation. Also, the typical concentric zonation of oncoids is not apparent in our material, but may have been lost by metasomatism.

\section{Model 4: Roll-up structures}

Roll-up structures are not uncommon in Precambrian sedimentary rocks (e.g., Simonson \& Carney, 1999; Eriksson et al., 2000). They are believed to form by a scroll-like deformation of a mud sheet, possibly as a result of desiccation. In order to form a complete roll or spiral, the sheet must have been highly cohesive, suggesting the presence of a microbial mat (Eriksson et al., 2000). The examples described in the literature (Simonson \& Carney, 1999; Eriksson et al., 2000) are highly reminiscent of Telemarkites, forming cigar-like, elongated structures, tapering at both ends. However, we have not observed obvious spiral structure in any of the Telemarkites studied, and the interpretation as roll-up structures is therefore so far inconclusive. The occasional oblique orientation of Telemarkites with respect to bedding is also difficult to explain under this model.

\section{Model 5: Elongation and orientation of concretions by groundwater flow}

The Telemarkites nodules occur in metasandstones interpreted as lacustrine, they have a partially carbonatecemented core, show a strong or even extreme tendency for preferred orientation (Fig. 3), and are commonly oblique to bedding. Also, they are in some cases crossed by the primary bedding, indicating that the nodules grew in the sediment post deposition. All these features are consistent with the elongated carbonate concretions discussed by e.g., Mozley \& Davis (2005) and McBride et al. (1994). These concretions formed during phreatic groundwater flow. Mozley \& Davis (2005) suggested that the concretions formed in elongated zones downstream of organic remains, also consistent with the possibly microbialitic textures of the Telemarkites host rock.

Oxygen isotope values in T. giganticus carbonate are very light, around $-18 \%$. This may reflect recrystallisation with replacement of oxygen at relatively high temperature during burial, in line with the inferred metamorphic grade. However, it is also possible that the original pore water was highly depleted in ${ }^{18} \mathrm{O}$. Mesoproterozoic marine carbonates typically show $\delta^{18} \mathrm{O}$ values in the -8 to $-10 \%$ range, probably reflecting seawater isotopic composition (Shields \& Veizer, 2002). Precipitation under meteoric water conditions (river or groundwater) would lead to further fractionation to lighter isotopes with respect to the marine values (e.g., Hays \& Grossman, 1991). The radial gradient in carbon isotopic composition was probably affected by 
metamorphic alteration to some extent, but carbon isotopic ratios are usually more robust than oxygen ratios and the lack of correlation with $\delta^{18} \mathrm{O}$ indicates that there was only limited late-burial fractionation in $\delta^{13} \mathrm{C}$. Both the range of $\delta^{13} \mathrm{C}$ and the rim-to-core gradient are similar to the elongated carbonate concretions described by McBride et al. (1994) from a groundwater flow system in Pleistocene sands in Italy. These authors reported a mean $\delta^{13} \mathrm{C}$ value of $-1.7 \%$ in detrital calcite grains in the host sand, reducing to $-5.5 \%$ in the concretions, indicating an organic source for some of the carbon in the concretion calcite.

Although the groundwater flow hypothesis for Telemarkites fits with many observations, it does not explain the concentration of carbonate in the core, the lack of sericite in the intermediate zone or the presence of the outer membrane. We can only postulate that these are unexplained effects of hydrothermal alteration with dissolution of minerals, mobilisation of ions and reprecipitation.

\section{Model 6: Eukaryotic macrofossils}

As no conclusive evidence was found for any of the hypotheses above, the second hypothesis of Dons (1959), namely that Telemarkites represents a eukaryotic macrofossil, must also be taken seriously, although Schopf \& Klein (1992) classified Telemarkites enigmaticus as non-biogenic, and the identification of Precambrian micro- and macrofossils is now often met with scepticism except in clear cases (e.g., Wacey, 2009). Dons (1959) suggested a sponge-like organism, possibly because of the central core which he described as an infilled cavity ('canal'). However, it is not obvious that the structures were originally hollow, and also the core seems to terminate inside the nodule at both ends in most (possibly not all) cases (Figs. 5 \& 12). This is not consistent with the open body cavity of sponges. Sponge fossils are rare and disputed even as late as the Ediacaran, and do not make an unequivocal appearance until the earliest Cambrian (e.g., Sperling et al., 2010; Botting \& Muir, 2018). Biomarkers and molecular clock evidence indicate that metazoans, and possibly even basal sponges, appeared already in the Cryogenian (Sperling et al., 2010), but the Telemarkites nodules are several hundred million years older than that, and therefore unlikely to represent sponges. The same conclusion was drawn by Pflug \& Strübel (1969). Still, we consider it possible that some other pre-metazoan eukaryotic organism of unknown affinity was responsible for the Telemarkites structures. Considering this eventuality, and because we think it is useful to distinguish between the large nodules described here and the smaller nodules found in another stratigraphic position by Dons (1959), we formally assign Linnean names to both forms below.

\section{Systematic paleontology}

Regnum Incertae sedis

Phylum uncertain

Class uncertain

Order uncertain

Family uncertain

Genus Telemarkites Dons, 1959.

Type species. Telemarkites enigmaticus Dons, 1959

Remarks. Dons (1959:262) concludes in his description of Telemarkites enigmaticus that the nodules are concretions formed by intervention of algae, or that the nodules represent sponges. Pflug \& Strübel (1969:155) conclude that Telemarkites enigmaticus is the result of development of algal colonies, and that there is no evidence that the structure is of sponge or stromatoporoid origin.

Telemarkites giganticus sp. nov. Gyøry, Hammer, Jorde, Nakrem, Swajda \& Domeier

Figures 5, 6, 8, 11, 12, 13

1972 Telemarkites giganticus Gyøry, 1972, p. 20, fig. 8 (unpublished thesis and therefore not a valid name).

Etymology. Giganticus, meaning gigantic, for its significantly larger size than that of Telemarkites enigmaticus.

Holotype. PMO 228.551.

Paratypes. PMO 228.552-553.

Type locality. Southeastern shore of Lake Breidvatn, Telemark, Norway, 59²3'53.6”N, 752’29.4”E.

Type horizon. From the middle part of the Amot Formation, Bandak Group, of the Telemark supracrustals. The Åmot Formation has not been dated, but the Fjellhovdane rhyolite in the overlying Skinnut Formation has recently been dated to $1233 \pm 10 \mathrm{Ma}$ (Roberts et al., 2011), thus providing a minimum age.

Diagnosis. Elongated nodule tapering at both ends. Cross sections mainly ellipsoidal. Apparently no shell, but inferred membraneous periphery; with a centrally located, inner core, in some cases extending down through the lowermost part of the outer periphery.

Description. Telemarkites giganticus is somewhat similar to Telemarkites enigmaticus, but is significantly larger, 
typically with a length of some $20-25 \mathrm{~cm}$. The shape is elongated, tapering in both directions to a blunt end. The nodule is somewhat flattened, resulting in ellipsoidal cross sections with diameters of 3-7 cm. It contains a centrally located inner core with a diameter of $0.4-0.7$ $\mathrm{cm}$ that also tapers in both directions. The lower end of the inner core in some cases appears to extend down through the lowermost part of the outer wall. The colour is pinkish-grey, with a greenish tint in the central core.

Measurements. Field orientations are shown in Fig. 3 and diameters of cross sections in Fig. 4.

Comparison. The main differences between Telemarkites giganticus and Telemarkites enigmaticus are their size and shape. Telemarkites giganticus is elongated with a longest axis of some $20-25 \mathrm{~cm}$ and shortest axis of some $3-4 \mathrm{~cm}$, while Telemarkites enigmaticus has a longest axis of 2.5$4.5 \mathrm{~cm}$ and a shortest axis of $1-2 \mathrm{~cm}$.

\section{Conclusions}

As Dons (1959) found for his Telemarkites enigmaticus nodules, we have not been able to give a single, unequivocal explanation for Telemarkites giganticus. Considering the multitude of Precambrian structures previously described as fossils but now considered pseudofossils (e.g., Schopf \& Klein, 1992), we find it prudent to be careful with interpreting Telemarkites as a eukaryotic fossil, especially considering its high age. However, because none of the other explanations we have considered fit perfectly with the observations, this possibility remains open.

The presence of algal mats or other microbial structures would not at all be surprising in sediments of this type and age, and interpretation of Telemarkites as a microbialite (whether oncoids or roll-up structures) is therefore possible. Among the abiotic explanations, formation of concretions by groundwater flow, later altered by metamorphism, seems a good candidate because of the preferred orientation, tilt with respect to bedding, cross-cutting relation with bedding, and carbon isotopes.

Acknowledgements. The hyperspectral imaging and MNF analysis were carried out by Lukas Paluchowski at Norsk Elektro Optikk AS. Bulk $\mathrm{XRD}$ and XRF analyses were done at Norsk Hydro Research Centre in Porsgrunn. Thanks to Nèlia Castro at NHM for help with SEM-EDS, to Morten Smelror at NGU for inspecting the palynological slides, and to Johan Petter Nystuen and Stefan Bengtson for useful discussions and helpful reviews.

\section{References}

Botting, J.P. \& Muir, L.A. 2018: Early sponge evolution: A review and phylogenetic framework. Palaeoworld 27, 1-29. https://doi.org/10.1016/j.palwor.2017.07.001.

Butterfield, N.J. 2000: Bangiomorpha pubescens n. gen., n. sp.: Implications for the evolution of sex, multicellularity, and the Mesoproterozoic/Neoproterozoic radiation of eukaryotes. Paleobiology 26, 386-404. https://doi.org/10.1666/0094-8373(2000)026<0386:BPNGNS>2.0.CO;2.

Dahlgren, S., Heaman, L. \& Krogh, T. 1990: Geological evolution and $\mathrm{U}-\mathrm{Pb}$ geochronology of the Proterozoic Central Telemark Area, Norway. Geonytt 17, 38-39.

Dons, J.A. 1959: Fossils (?) of Precambrian age from Telemark, southern Norway. Norsk Geologisk Tidsskrift 39, 249-262.

Dons, J.A. \& Jorde, K. 1978: Berggrunnskart Skien, scale 1:250,000. Geological Survey of Norway.

Eriksson, P.G., Simpson, E.L., Eriksson, K.A., Bumby, A.J., Steyn, G.L. \& Sarkar, S. 2000: Muddy roll-up structures in siliciclastic interdune beds of the c. 1.8 Ga Waterberg Group, South Africa. Palaios 15, 177-183.

https://doi.org/10.1669/0883-1351(2000)015<0177:MRUSIS>2.0.CO;2.

Flügel, E. 2004: Microfacies of carbonate rocks. Springer, 976 pp. https://doi.org/10.1007/978-3-662-08726-8.

Gnilovskaya, M.B. 1998: The oldest annelidomorphs from the Upper Riphean of Timan. Doklady Akademii Nauk 359, 369-372.

Gyøry, E. 1972: Geologisk og gravimetrisk undersøkelse i BandakFyresdalområdet, Telemark. Cand. real. thesis, University of Oslo, Oslo, Norway, 218 pp., with maps and illustrations (54 pp).

Han, T.M. \& Runnegar, B. 1992: Megascopic eukaryotic algae from the 2.1-billion-year-old Negaunee Iron-Formation, Michigan. Science 257, 232-235. https://doi.org/10.1126/science.1631544.

Hays, P.D. \& Grossman, E.L. 1991: Oxygen isotopes in meteoric calcite cement as indicators of continental paleoclimate. Geology 19, 441444 .

https://doi.org/10.1130/0091-7613(1991)019<0441:OIIMCC>2.3.CO;2.

Jimenez-Lopez, C., Romanek, C.S. \& Bazylinski, D.A. 2010: Magnetite as a prokaryotic biomarker: A review. Journal of Geophysical Research 115, G00G03. https://doi.org/10.1029/2009JG001152.

Knoll, A.H. 2014: Paleobiological perspectives on early eukaryotic evolution. Cold Spring Harbor Perspectives in Biology 6, 1-14. https://doi.org/10.1101/cshperspect.a016121.

Knoll, A.H., Javaux, E.J., Hewitt, D. \& Cohen, P. 2006: Eukaryotic organisms in Proterozoic oceans. Philosophical Transactions of the Royal Society of London B 361, 1023-1038. https://doi.org/10.1098/rstb.2006.1843.

McBride, E.F., Picard, M.D. \& Folk, R.L. 1994: Oriented concretions, Ionian Coast, Italy: Evidence of groundwater flow direction. Journal of Sedimentary Research A64, 535-540.

Mozley, P.S. \& Davis, J.M. 2005: Internal structure and mode of growth of elongate calcite concretions: Evidence for small-scale, microbially induced, chemical heterogeneity in groundwater. Geological Society of America Bulletin 117, 1400-1412. https://doi.org/10.1130/B25618.1.

Pflug, H.D. \& Strübel, G. 1969: Algen und Bakterien in Präkambrischen Konkretionen. Paleontographica Abteilung B 127, 143-158.

Roberts, N.M.W., Parrish, R.R., Horstwood, M.S.A. \& Brewer, T.S. 2011: The 1.23 Ga Fjellhovdane rhyolite, Grøssæ-Totak; a new age within the Telemark supracrustals, southern Norway. Norwegian Journal of Geology 91, 239-246.

Schopf, J.W. \& Klein, C. 1992: The Proterozoic biosphere - a multidisciplinary study. Cambridge University Press, 1374 pp. https://doi.org/10.1017/CBO9780511601064.

Schopf, J.W., Kudryavtsev, A.B., Sugitani, K. \& Walter, M.R. 2010: Precambrian microbe-like pseudofossils: A promising solution to the problem. Precambrian Research 179, 191-205. https://doi.org/10.1016/j.precamres.2010.03.003. 
Shields, G. \& Veizer, J. 2002: Precambrian marine carbonate isotope database: Version 1.1. Geochemistry, Geophysics, Geosystems 3, 1-12. https://doi.org/10.1029/2001GC000266.

Sigmond, E.M.O. 1998: Berggrunnskart Odda, scale 1:250,000. Geological Survey of Norway.

Sigmond, E.M.O., Jorde, K., Gyøry, E. \& Gjelle, S. 2015: Berggrunnskart Borsæ 1513-4, scale 1:50,000. Geological Survey of Norway.

Simonson, B.M. \& Carney, K.E. 1999: Roll-up structures: Evidence of in situ microbial mats in late Archean deep shelf environments. Palaios 14, 13-24. https://doi.org/10.2307/3515358.

Singh, I.B. 1969: Primary sedimentary structures in Precambrian quartzites of Telemark, Southern Norway, and their environmental significance. Norsk Geologisk Tidsskrift 49, 1-31.

Sperling, E.A., Robinson, J.M., Pisani, D. \& Peterson, K.J. 2010: Where's the glass? Biomarkers, molecular clocks, and microRNAs suggest a 200-Myr missing Precambrian fossil record of siliceous sponge spicules. Geobiology 8, 24-36. https://doi.org/10.1111/j.1472-4669.2009.00225.x.

Zwicker, J., Smrzka, D., Gier, S., Goedert, J.L. \& Peckmann, J. 2015: Mineralized conduits are part of the uppermost plumbing system of Oligocene methane-seep deposits, Washington State (USA). Marine and Petroleum Geology 66, 616-630. https://doi.org/10.1016/j.marpetgeo.2015.05.035.

Wacey, D. 2009: Early life on Earth: A practical guide. Springer, 274 pp. https://doi.org/10.1007/978-1-4020-9389-0. 